\title{
Analysis on Brand Preference and Loyalty of Physical Education and Sports Teachers
}

\author{
Serdar Orhan", Zeynep Kaplan \\ Faculty of Sports Sciences, Firat University, Turkey
}

Copyright $(\mathrm{O} 2018$ by authors, all rights reserved. Authors agree that this article remains permanently open access under the terms of the Creative Commons Attribution License 4.0 International License

\begin{abstract}
The purpose of this study is to determine the factors affecting brand preference and loyalty of physical education and sports teachers and to analyse it according to the demographic characteristics. The research population is composed of 265 physical education teachers working in Elazı $\breve{g}$ province. The research sample is composed of 158 male and 39 female as a total of 197 voluntary physical education teachers working in Elazı $\breve{g}$ province in 2016-2017 academic year. As a data collection tool, Personal Information Form prepared by the researcher and Brand Preference and Loyalty Scale developed by Çifci were used. Mann Whitney U and Kruskal Wallis H tests among the statistical analyses were used and $\mathrm{p}<0.05$ was accepted as the significance level. In conclusion, high preference of physical education teachers with an income level of 2001-2500 TL for branded product and the low level loyalty of physical education teachers with a bachelor degree for branded products were significant. It has been observed that the physical education teachers working as permanent teachers in public schools consider brand and quality equal and they attach importance to the quality in preferring branded products. It has been determined that the higher the demand for branded products is, the higher the income level becomes. The brands of Adidas, Nike and Hummel have been found to be preferred more.
\end{abstract}

Keywords Brand, Attitude, Sports, Buying, Preference

\section{Introduction}

The concept of a brand is a phenomenon based on very ancient histories. In the excavations performed by the researchers, many handprints believed to have dated back to BC. 15 and being the indicators of possession were found in the walls of Lascaux Caves in Southern France. Old civilizations such as Egyptians, Greeks, Romans and Chinese also formed the concept of brand by putting stamps on pottery and other items to indicate ownership and quality [22].
Creating a brand has reached today as a result of the efforts of producers to separate their products from others for centuries [23]. For the last two decades, the brand concept has been among the most important assets of companies [21]. Today's modern marketing approach requires businesses to achieve customer satisfaction at the highest level to ensure customer loyalty. In order to determine the relation between high level satisfaction and a strong loyalty, it becomes obligatory to conduct a market research which includes a well investigation of consumer preferences and determining the factors affecting the brand preference [5].

While brand name and brand value have been emphasized recently, brand name is perceived as an increasing value for consumers. In addition, brand value provides advantages over image of consumers, marketing location and changing prices. This is why brand value affects sales behaviour during marketing [10].

The brand concept is expressed as a special name or sign that describes a commodity or any object and distinguishes it from other similar ones [7]. According to another definition, the brand is the identity of the products of the manufacturer or the seller and distinguishing symbol for competitor goods [15]. Another definition is that brand can be expressed as a name or symbol that defines goods and services reaching to consumer and distinguishes itself from others [18].

With a more clear meaning, brand awareness, brand interest, competence of brand, reputation of the brand and trust in the firm have been found to be as the factors related to the confidence in a brand [17]. Brand image is critical in attire purchase behavior as it interact consumers choices and purchase intent as well as their zeal to bear a high price and advocate the brand to others [19]. Brand reputation is defined as a collective representation or aggregate of images associated with a brand over-time [25]. Branding is an asset, expressed as credibility, a long- term investment, loyalty, an assurance for consumer choice for past, present and future which automatically gets the brand sustainability [19].

Looking from another perspective, any consumer can prefer and buy any product and brand as s/he perceives it as 
an indicator of social status or integrates the brand image with her/his own image. The social class or the title owned by the individual can make the brand important [1]. No doubt, immediacy, and self-connection are the part of the emotional dimension of brand relationship, while satisfaction, trust and attachment are either antecedents or consequences of such relationships between consumers and brand [25].

An increase in the price of the consumer's most preferred brand may affect the consumer's brand loyalty negatively. However, consumers are creating a psychological bond with their brands due to brand image, brand identity, experience and emotion related to the brand and pay more for these brands. However, consumers who think that there are not big differences between brands today focus on the idea that brands can easily take each other's place. Consumers in this opinion also buy an acceptable brand that is on sale [16].

The re-buying behaviour, which is regarded as a measure of brand loyalty, does not take into account the feelings of the consumer for the brand re-bought and it isn't possible to explain why the consumer always buys this brand and whether s/he really likes it. The difference between the consumer's choosing a brand for habit or convenience and the fact that s/he really adopts and buys for loving it should be determined. Consumers also continue to buy the same brands due to low price or the absence of a better alternative [13].

Generally speaking, neuroscientific methods are used to study consumer behavior and the decision-making processes in purchasing acts. Neuroeconomics is a new field of interdisciplinary research that emerged around the turn of the 21st century. It calls for new conceptual, theoretical, as well as methodological developments in combining cognitive neuroscience, computational neuroscience, psychology, and economics to carry out in vivo investigations of the brain processes involved when individuals make economically relevant decisions [12].

Neuromarketing represents a new area of marketing implementation in order to reach strategic decisions. While marketing is trying to understand the psychology of human behavior, neuromarketing is trying to understand the biology of human behavior. It has been suggested neuromarketing as a novel research area which is composed of "neuroscience" and "marketing". In the field of advertising, NM has been defined as "applying the methods of the neurology lab to the questions of the advertising world" [26].

However, after years of controversy subliminal advertising has recently been shown to be effective, but only under certain conditions. Recent literature testing the effects of subliminal priming on consumption behaviors suggested that priming only works if primed behaviors match biological or psychological need. Subliminal persuasion research suggests that subliminal stimuli affect action when that action seems relevant to conscious physical need states [3].
Physical education teachers are responsible for the conduct of physical education classes. Since the working environment is very important to choose the right sport shoes and clothes for success, health and the protection from accidents of teachers. Moreover, the brand of sportswear to be chosen can be one of the factors affecting the teacher in sports achievement or course success, and this can be a factor for the teacher's preference for brand.

The purpose of this study is to determine the factors affecting brand preference and loyalty of physical education and sports teachers and to analyse it according to the demographic characteristics.

\section{Materials and Methods}

\subsection{Population and Sampling}

The research population is composed of 265 physical education teachers working in Elazı $\breve{g}$ province. The research sample is composed of 158 male and 39 female as a total of 197 voluntary physical education teachers working in Elazığ province in 2016-2017 academic year. The study was conducted in accordance with the Declaration of Helsinki, and the protocol was approved by the Ethics Committee of Firat University Non-Interventional Research. Face-to-face interviews were held with the physical education teachers, information was given regarding that they could not be used anywhere other than the purpose of this study, and questionnaires were filled in on a volunteer basis. The questionnaire prepared to obtain data within the scope of research was applied to 216 physical education teachers, 19 of forms were excluded due to being inappropriate for the analysis and a total of 197 questionnaires were evaluated.

\subsection{Data Collection Techniques}

As a data collection tool, Personal Information Form prepared by the researcher and Brand Preference and Loyalty Scale developed by Çifci (2006) were used.

\subsection{Data Collection Tools}

The questions of 13-item Personal Information Form are related to the school worked, sex, age, marital status, education, type of employment, income, frequency of shopping, association of brand concept, the reason of preferring branded product, preference for the products with same price, generally used brands and procurement place of branded products.

Brand Preference and Loyalty Scale is composed of 2 parts. There is a 20-question attitude scale to ascertain the brand preferences. This attitude scale is a 5-point Likert scale and prepared as Very Significant (5), Significant (4), Neutral (3), Insignificant (2) and Very Insignificant (1). In the second part of the questionnaire, a 5-point Likert type 
attitude scale composed of 13 questions has been prepared in order to determine loyal customer profiles and brand loyalties. In this scale, the questions numbered 1, 2, 3, 4, 6, 9, 10 and 12 are graded as Totally Agree (1), Agree (2), Hesitant (3), Disagree (4) and Totally Disagree (5). The role of inverse questions in increasing the reliability of questionnaires is considerably high. Thus, the questions of $5,7,8,11$ and 13 are asked inversely and graded as Totally Agree (5), Agree (4), Hesitant (3), Disagree (2) and Totally Disagree (1). The main purpose of this scale is to reveal the profile of loyal customers. The internal consistency coefficient (Cronbach Alfa coefficient) of the scale was found to be .86 [15]. The internal consistency coefficient of this study (Cronbach Alfa coefficient) was found to be .85 .

\subsection{Statistical Analysis}

Descriptive statistics were used to summarize the demographic and personal information of the sample group and the data were evaluated in the statistical package program. Mann Whitney U was used in paired comparisons after the normality test and Kruskal Wallis $\mathrm{H}$ test was used in the intergroup comparisons. The significance level of $\mathrm{p}<0.05$ was accepted as the statistical significance.

\section{Results}

Looking at frequency and percentage distributions of data obtained, it is observed that $80.2 \%$ of the participant physical education teachers $(\mathrm{n}=158)$ are male, $67 \%$ of them $(n=132)$ are married, $93.4 \%$ of them $(n=184)$ work in public schools, $90.4 \%(\mathrm{n}=178)$ works as permanent staff, $85.3 \%(n=168)$ has a bachelor degree and $56.9 \%(n=112)$ is in the age group of $31-40.45 .7 \%(n=90)$ of the physical education teachers are in the income level of 2500-3001 TL, the shopping frequency of $52.3 \%$ of them $(n=103)$ is irregular, $65.0 \%(\mathrm{n}=128)$ buys the branded product from the store and $68.5 \%(n=135)$ prefers the high quality generic products for the products of same price (Table 1).

Table 1. The comparison of the brand preference attitudes and brand loyalty means of physical education teachers with the variables

\begin{tabular}{|c|c|c|c|c|c|c|c|c|c|}
\hline \multirow[b]{2}{*}{ Variables } & & \multirow[b]{2}{*}{$\mathbf{x}$} & \multirow[b]{2}{*}{$\%$} & \multicolumn{3}{|c|}{ Brand Preference Attitude } & \multicolumn{3}{|c|}{ Brand Loyalty } \\
\hline & & & & $\begin{array}{l}\text { Mean } \\
\text { Rank }\end{array}$ & $\mathbf{U}$ & $\mathbf{p}$ & $\begin{array}{l}\text { Mean } \\
\text { Rank }\end{array}$ & $\mathbf{U}$ & $\mathbf{p}$ \\
\hline \multirow[t]{2}{*}{ Sex } & Male & 158 & 80.2 & 96.08 & 2620.00 & 0.148 & 97.84 & 2897.00 & 0.564 \\
\hline & Female & 39 & 19.8 & 110.82 & & & 103.71 & & \\
\hline \multirow[t]{2}{*}{ Marital Status } & Single & 65 & 33.0 & 89.03 & 3642.000 & 0.088 & 103.95 & 3968.500 & 0.392 \\
\hline & Married & 132 & 67.0 & 103.91 & & & 96.56 & & \\
\hline \multirow[t]{2}{*}{ Workplace } & Public & 184 & 93.4 & 99.75 & 1058.50 & 0.489 & 99.35 & 1131.00 & 0.743 \\
\hline & Private & 13 & 6.6 & 88.42 & & & 94.00 & & \\
\hline \multirow[t]{2}{*}{ Type of Employment } & Permeant & 178 & 90.4 & 99.80 & 1548.500 & 0.546 & 98.98 & 1688.000 & 0.990 \\
\hline & Paid & 19 & 9.6 & 91.50 & & & 99.16 & & \\
\hline \multirow[t]{2}{*}{ Education } & Undergraduate & 168 & 85.3 & 102.22 & 1894.500 & 0.056 & $94.59^{\mathrm{b}}$ & 1694.500 & $0.009^{* a}$ \\
\hline & Graduate & 29 & 14.7 & 80.33 & & & 124.57 & & \\
\hline \multirow[t]{3}{*}{ Price Preference } & Low Quality & 62 & 31.5 & 96.92 & 4056.00 & 0.728 & 91.53 & 3722.00 & 0.212 \\
\hline & High Quality & 135 & 68.5 & 99.96 & & & 102.43 & & \\
\hline & & & & & $x^{2}$ & $\mathbf{p}$ & & $x^{2}$ & $\mathbf{p}$ \\
\hline \multirow[t]{4}{*}{ Age } & $21-30$ & 55 & 27.9 & 101.26 & 2.61 & 0.454 & 101.30 & 1.54 & 0.673 \\
\hline & $31-40$ & 112 & 56.9 & 97.15 & & & 99.31 & & \\
\hline & $41-50$ & 29 & 14.7 & 98.79 & & & 91.53 & & \\
\hline & $51+$ & 1 & 0.5 & 187.50 & & & 154.50 & & \\
\hline \multirow[t]{4}{*}{ Income } & $1500-2000 \mathrm{TL}$ & 24 & 12.2 & 88.13 & 9.168 & $0.027^{* a}$ & 92.69 & 3.120 & 0.374 \\
\hline & $2001-2500 \mathrm{TL}$ & 8 & 4.1 & $156.75^{\mathrm{b}}$ & & & 107.63 & & \\
\hline & 2501-3000 TL & 90 & 45.7 & 97.63 & & & 92.94 & & \\
\hline & $3000 \mathrm{TL}+$ & 75 & 38.1 & 97.97 & & & 107.37 & & \\
\hline \multirow[t]{4}{*}{$\begin{array}{l}\text { Frequency of } \\
\text { Shopping }\end{array}$} & Everyday & 20 & 10.2 & 87.43 & 7.624 & 0.054 & 95.85 & 6.473 & 0.091 \\
\hline & Weekly & 38 & 19.3 & 105.61 & & & 97.29 & & \\
\hline & Monthly & 36 & 18.3 & 78.36 & & & 79.35 & & \\
\hline & Irregular & 103 & 52.3 & 106.02 & & & 107.11 & & \\
\hline Procurement Place & Store & 128 & 65.0 & 95.86 & 3.876 & 0.144 & 99.03 & 0.003 & 0.999 \\
\hline \multirow[t]{3}{*}{ of Branded Product } & $\begin{array}{c}\text { Virtual } \\
\text { Environment }\end{array}$ & 33 & 16.8 & 116.74 & & & 99.30 & & \\
\hline & Shopping centres & 36 & 18.3 & 93.92 & & & 98.63 & & \\
\hline & Other & 0 & 0.0 & 0 & & & 0 & & \\
\hline
\end{tabular}

$* \mathrm{p}<0.05{ }^{\mathrm{a}}$ Intergroup difference ${ }^{\mathrm{b}}$ The group being the source of difference 
When brand preference attitude and brand loyalty averages of physical education teachers are compared to the variables and when sub-dimension score averages of the participants by the variable of education are compared in terms of Mann Whitney $U$ test results, a statistically significant difference has been observed in score averages of sub-dimensions $(\mathrm{U}=1694.500 ; \mathrm{p}<0.05)$. Due to the fact that the mean rank of undergraduate education level is lower according to graduate education level in the sub-dimension of "Brand Loyalty", it has been ascertained that the difference arises from this group $\left(94.59^{\mathrm{b}}\right)$. When the sub-dimension mean scores of the participants by the variable of income are compared in terms of the Kruskal Wallis $\mathrm{H}$ test results performed for more than two groups, it has been observed that there is a statistically significant difference in the mean scores of the sub-dimension "Brand Preference Attitudes" $\left(x^{2}=9.168 ; p<0.05\right)$. In order to establish from which group this difference arises, Mann Whitney $U$ test used in paired comparisons was applied and due to the fact that mean ranks of the income level "2001-2500 TL" are higher than other income levels in the sub-dimension of "Brand Preference Attitudes", the difference has been found to be arising from this group $\left(156.75^{\mathrm{b}}\right)$. No statistically significant difference has been found by the variables of sex, age, marital status, workplace, type of employment, price preference, shopping frequency and procurement place of branded products $(\mathrm{p}>0.05)$ (Table 1$)$

The physical education teachers have given the answer of Quality most with $43.3 \%$ for the question "What does the concept of brand evoke to you?" in which they can select more than one answer (Table 2).

Table 2. Frequency and percentage distribution of the answers given to the question "What does the concept of brand evoke to you?"

\begin{tabular}{ccccc}
\hline & & \multicolumn{3}{c}{ Responses } \\
\cline { 3 - 5 } & & $\mathrm{N}$ & Percent & $\begin{array}{c}\text { Percent of } \\
\text { Cases }\end{array}$ \\
\hline \multirow{2}{*}{$\begin{array}{c}\text { Quality } \\
\text { What does the }\end{array}$} & 197 & $43.3 \%$ & $100.0 \%$ \\
concept of brand & Prese to you? & 78 & $17.1 \%$ & $39.6 \%$ \\
& Prower & 18 & $4.0 \%$ & $9.1 \%$ \\
& Professionalism & 33 & $7.3 \%$ & $16.8 \%$ \\
& Fame & 9 & $2.0 \%$ & $4.6 \%$ \\
Total & Satisfaction & 79 & $17.4 \%$ & $40.1 \%$ \\
& & 258 & $100.0 \%$ & $231.0 \%$ \\
\hline
\end{tabular}

The physical education teachers have given the answer of 'It is high-quality' most with $47.9 \%$ for the question "Why do you prefer branded products?" in which they can select more than one answer (Table 3).
Table 3. Frequency and percentage distribution of the answers given to the question "Why do you prefer branded products?"

\begin{tabular}{|c|c|c|c|c|}
\hline & & \multicolumn{3}{|c|}{ Responses } \\
\hline & & $\mathrm{N}$ & Percent & $\begin{array}{l}\text { Percent of } \\
\text { Cases }\end{array}$ \\
\hline \multirow{5}{*}{$\begin{array}{l}\text { Why do you prefer } \\
\text { branded products? }\end{array}$} & It is high-quality & 197 & $47.9 \%$ & $100.0 \%$ \\
\hline & $\begin{array}{l}\text { I know that } \\
\text { product }\end{array}$ & 49 & $11.9 \%$ & $24.9 \%$ \\
\hline & $\begin{array}{l}\text { It gives to me a } \\
\text { positive image }\end{array}$ & 11 & $2.7 \%$ & $5.6 \%$ \\
\hline & I trust in it & 104 & $25.3 \%$ & $52.8 \%$ \\
\hline & $\begin{array}{l}\text { It responds to } \\
\text { my pleasure }\end{array}$ & 50 & $12.2 \%$ & $25.4 \%$ \\
\hline Total & & 411 & $100.0 \%$ & $208.6 \%$ \\
\hline
\end{tabular}

The physical education teachers have given the answer of Adidas with $31.6 \%$, Nike with $29.3 \%$ and Hummel with $22.3 \%$ most for the question "Which brands do you generally use?" in which they can select more than one answer (Table 4).

Table 4. Frequency and percentage distribution of the answers given to the question "Which brands do you generally use?"

\begin{tabular}{ccccc}
\hline & & \multicolumn{3}{c}{ Responses } \\
\cline { 3 - 5 } & & $\mathrm{N}$ & Percent & $\begin{array}{c}\text { Percent of } \\
\text { Cases }\end{array}$ \\
\hline & Adidas & 167 & $31.6 \%$ & $84.8 \%$ \\
& Nike & 155 & $29.3 \%$ & $78.7 \%$ \\
Which brands do you & Puma & 70 & $13.2 \%$ & $35.5 \%$ \\
generally use? & Hummel & 118 & $22.3 \%$ & $59.9 \%$ \\
& Slazenger & 1 & $.2 \%$ & $.5 \%$ \\
& Kinetix & 1 & $.2 \%$ & $.5 \%$ \\
Total & & 529 & $100.0 \%$ & $268.5 \%$ \\
\hline
\end{tabular}

\section{Discussion}

Depending on the factors affecting the buying behaviour, consumers prefer one brand to another. Various factors also play a role in the reason for this preference. The demographic characteristics of the person are one of these factors. Analyses were performed according to the demographic characteristic of consumers within the scope of this research.

A total of 197 physical education teachers composed of 158 males and 39 females participated in this study which is performed to determine the brand preference and loyalty of physical education teachers and to analyse them according to demographic characteristics. 
Looking at the answers given to brand preference and loyalty scale in the study, it has been observed that most of the physical education teachers preferring both branded product and looking for certain brands for the preferred branded products are female, work in public schools, prefer the high-quality generic products with the same price, in the age group of 21-30 and have an income of 2001-2500 TL, do shopping irregularly and buy the branded product via the virtual environment.

In previous studies, it has been stated that no significant difference has been found between brand attitude and loyalty by sex similarly with this study [6], and male students are more loyal consumers than female students as different from our study [13]. It is also stated that brand loyalty reduces as age increases $[6,24]$. In the study of Ceritoğlu (2004), it has been stated that young people aren't affected from price reductions and promotions while buying gym shoes. The fact that physical education teachers prefer high quality generic products with the same price supports the literature [4].

The fact that the physical education teachers are able to get answers to their positive attitudes and expectations towards the brands they use can lead them to buy the same brand again. If consumers are pleased with the product / brand they use, they prefer the same brand for the next purchase [13]. Also reductions attaching the consumer to the brand, product display format, special prices, intensive advertising efforts, promotions, past experiences, reference groups and social classes, and easy availability of the brand at any time and place facilitate and increase the repurchases [9].

It has been observed that most of the physical education teachers preferring branded product but not searching certain brands in the preferred branded products i.e. those not showing brand loyalty are married, work as a permanent staff and have an undergraduate degree. These results show that the budget friendly products and satisfaction arising from their use affect their brand preference [8]. In the study of Göksu (2010), it has been stated that the awareness of brand or brand recognition i.e. over-recognition of a brand isn't a factor alone in formation of a brand loyalty for purchasing [13]. It is also determined in the study that the high level in the branded product preference of physical education teachers with an income level of 2001-2500 TL is significant. This situation may be due to the fact that physical education teachers with this income group do not present the same significance in brand loyalty and the number of participants is small. As a matter of fact, it is reported that as the level of income increases, brand loyalty reduces. As the income level increases, customers show less loyalty towards a certain brand. The lower-income customers have limited product and brand types and usually prefer a certain brand. However, high-income customers can constantly change their preferences within a wide range of brands and products. They frequently desire to try the new brands in the market.
The low-income customers avoid the risks to be brought by the new product [6]. As they hesitate to undertake the financial risk, a loyalty towards branded products can be in question [14].

It is observed in the study that low-level loyalty of the physical education teachers with an undergraduate degree towards branded products is significant. It is uttered in literature that as the education level increases, the trust felt towards the branded products decreases. As the level of education increases, it may be possible to search for more products and to prefer the most profitable brand [14].

For the question "What does the concept of brand evoke to you?" directed to physical education teachers, the answer given is Quality (43.3\%) and "The reason for preferring branded product" is indicated as High-quality $(47.9 \%)$. In previous studies, it is expressed as similar to this study that quality is deemed more important than the brand, branded clothes are an indicator of quality [11] and the well-known branded products are of higher quality [20]. Other studies are in similar quality $[6,13]$. It is seen that the first three answers given to the question "Which brands do you generally use?" are Adidas (31.6\%), Nike (29.3\%) and Hummel (22.3\%) brands. In the study of Göksu (2010) performed on brand loyalty of physical education teachers, it has been stated that the most remembered sports brands are Nike, Adidas, Puma and Reebok and brand awareness and recognition are an important element in emotional brand loyalty of students [13]. This may be the result; it may be a sign of countries playing a leading role in the sport sector, with countries holding many economic sectors around the world [2].

This study bears some limitations. The study is limited to physical education teachers in Elazığ province. Subsequent studies may include more cities and participants. Another limitation is the wide range of branded products. Specific studies on different categories of sport products can define brand attitudes and loyalty and increase clear- ness and generalizability.

In conclusion, the high level in branded product preference of physical education teachers with an income level of 2001-2500 TL and the low level in branded product loyalty of physical education teachers having an undergraduate degree are significant. It is observed that the physical education teachers most of whom work in public schools as a permanent staff consider brand and quality equal and they give importance to the quality in their branded product preference. It has been ascertained that as the income level increases, the demand for branded products also increase and the prominent brands in branded product preference are Adidas, Nike and Hummel.

Based on research results, it can be stated that branded clothing should be deemed important in that it helps physical education teachers increase their self-confidence, strengthens their current and future positions, it is thought by others as a liking, a prestige factor and having a certain image. 


\section{Acknowledgements}

The authors thank all physical education teachers for their participation.

\section{Conflicts of Interest}

The authors declare no conflict of interest.

\section{Funding}

This research received no external funding.

\section{REFERENCES}

[1] Ağaoğlu, Y.S. (2013). Beden Eğitimi ve Spor Yüksekokulu Öğrencilerinin Marka Tercihlerinin İncelenmesi, KMU Sosyal ve Ekonomik Araştırmalar Dergisi. 15 (25), 37-46.

[2] Batmaz, H. Ç., Yıldırım, F., Karadağ, M. (2016). The Effect of Global Competition on Sport Industy. The Journal of Academic Social Science Studies, 1(42), 521-534. https://doi.org/10.9761/JASSS3207

[3] Bermeitinger, C., Goelz, R., Johr, N., Neumann, M., Ecker, U.K.H. and Doerr, R. (2009). The hidden persuaders break into the tired brain, Journal of Experimental Social Psychology, 45 (2), pp. 320-326. doi: 10.1016/j.jesp.2008.10.001

[4] Ceritoğlu, A.B. (2004). Genç Tüketicilerde Marka Bilincinin Oluşması ve Marka Sadakati Kavramlarının İncelenmesi ve Konu İle İlgili Bir Uygulama. Marmara University Institute of Social Sciences, $\mathrm{PhD}$ Thesis. İstanbul.

[5] Çakır, M., Çakır, F., Usta, G. (2010). Üniversite Ögrencilerinin Tüketim Tercihlerini Etkileyen Faktörlerin Belirlenmesi. Organizasyon ve Yönetim Bilimleri Dergisi. $2(2), 87-94$.

[6] Çifci, S. (2006). Marka Ve Marka Sadakati Üniversite Öğrencilerinin Kot Pantolon Marka Tercihleri Ve Marka Sadakatleri İle İlgili Bir Araştırma. Abant İzzet Baysal University Institute of Social Sciences, Master's Thesis, Bolu.

[7] Çifci, S., Cop, R. (2007). Marka ve Marka Yönetimi Kavramları: Üniversite Öğrencilerinin Kot Pantolon Marka Tercihlerine Yönelik Bir Araştırma. Finans, Politik \& Ekonomik Yorumlar. 44 (512), 69-88.

[8] Demir, N. (2013). Genç Tüketicilerin Demografik Özelliklerinin Marka Tercih Etme Nedenlerinde Ve Marka Sadakatlerinde Olușturduğu Farkliliğin Belirlenmesi. Niğde University Institute of Social Sciences, Department of Production Management and Marketing, Master's Thesis, Niğde.

[9] Dick, A.S., Basu, K. (1994). Customer Loyalty: Toward Integrated Conceptual Framework, Journal of Academy of
Marketing, 22, 99-113. doi:10.1177/0092070394222001

[10] Ding, J.F., Lee, K.L., Lin, S.C. (2011). An empirical study on assessing brand equity for global shipping carrier-based logistics service providers African Journal of Business Management. 5(16), 6756-6763. doi: $10.1177 / 0092070394222001$

[11] Erdal, G., Erdal, H., Uzundal, H. (2013). Gaziosmanpaşa Üniversitesi Öğrencilerinin Marka Giyim Konusundaki Tutum ve Davranışları Üzerine Bir Araştırma, Gaziosmanpaşa Bilimsel Araştırma Dergisi, 4, 49-56.

[12] Glimcher, P.W., Camerer, C.F., Fehr, E., A. Poldrack, R.A. (2009). "Introduction: A Brief History of Neuroeconomics," Neuroeconomics: decision making and the brain, 1 st Edition, Academic Press, 527-538. https://doi.org/10.1016/B978-0-12-374176-9.00041-5

[13] Göksu, F. (2010). Spor Ürünlerine Yönelik Marka Sadakati Üzerine Bir Araştırma. İstanbul University İletişim Fakültesi Dergisi, 39, 43-58.

[14] Gürbüz, A., Doğan, M. (2013). Indicating the relationship between the brand loyalty and consumer trust, Int. Journal of Management Economics and Business, 9 (19), 239-258. doi: 10.11122/ijmeb.2013.9.19.345

[15] İslamoğlu, A.H. (1996). Pazarlama Yönetimi ve Uygulamalar1. No publishing house, Kocaeli.

[16] Kotler, P. (1994) Marketing Management: Analysis, Planning, Implementation and Control, $8^{\text {th }}$ Edition, Prentice-Hall, Inc., New Jersey, 450.

[17] Kurtuldu, H.S. (2008). Markalı Ürünler Kullananları Kullanmayanlardan Ayıran Faktörler. Sosyal Bilimler Enstitüsü Dergisi. 25 (2), 71-88.

[18] Nadi, M.A., Ghahremani, N. (2011). Brand value and relationship performance in business markets: Across cultural glance of business services. African Journal of Business Management. 5(22), 9322-9333. doi:11.5897/AJBM11.959

[19] Naveed, F., Babur, M.N. (2011). The Real Battle Starts Now, Moving Beyond Brand Management, Interdisciplinary Journal of Contemporary Research in Business, 2/12, pp. 629- 634.

[20] Nazik, H.M. (2001). Tüketicilerin Satın Alımlarında Markaya İlişkin Tutum ve Davranışlarına Farklı Tüketici Özelliklerinin Etkisi. Mesleki Eğitim Dergisi, 3, 93-116.

[21] Nijssen, E.J. (1999). Success factors of line extensions of fast-moving consumer goods. European Journal of Marketing. 33 (5/6), 450-469. doi: $10.1108 / 03090569910262044$

[22] Perry, A., Wisnom, D. (2003). Markanın DNA's1. (Edit: Zeynep Y1lmaz). MediaCat Press, İstanbul, p.12.

[23] Sadeghi, T., Tabrizi, K.G., Noroozi, A. (2011). The effective factors related with feelings, brand perception and purchase decision under a model. African Journal of Business Management. 5(30), 12025-12030. doi:10.5897/AJBM11.1084

[24] Sönmez, E. (2010). “Giyimde Marka Bağımlılığı ve Marka Duyarlılı̆̆1: Gençler Üzerine Bir Araștırma", Erciyes University Sosyal Bilimler Enstitüsü Dergisi, (28), 67-91. 
[25] Veloutsou, C., Moutinho, L., (2009). Brand relationships through brand reputation and brand tribalism, Journal of Business Research, 62 (3), pp. 314-322. https://doi.org/10.1016/j.jbusres.2008.05.010
[26] Wilson, R.M., Gaines, J., Hill, R.P. (2008). Neuromarketing and consumer free will, The Journal of Consumer Affairs, 42 (3), pp. 398-410. doi:10.1111/j.1745-6606.2008.00114.x. 